\title{
Expression of Streptococcus mutans fimA is iron-responsive and regulated by a DtxR homologue
}

\author{
Grace Spatafora, ${ }^{1}$ Meagan Moore, ${ }^{1}$ Susan Landgren, ${ }^{1}$ Emily Stonehouse ${ }^{1}$ \\ and Suzanne Michalek ${ }^{2}$
}

Author for correspondence: Grace Spatafora. Tel: +1 802443 5431. Fax: +1 8024432072. e-mail: spatafor@middlebury.edu

\footnotetext{
1 Department of Biology, Middlebury College, Middlebury, VT 05753, USA

2 Department of Microbiology, The University of Alabama at Birmingham, Birmingham, AL 35294, USA
}

\begin{abstract}
Iron uptake, transport and storage in Streptococcus mutans, the principal causative agent of human dental cavities, is unexplored despite early reports in the literature which predict a role for this trace metal in cariogenesis. Experiments in the authors' laboratory revealed several iron-responsive proteins in S. mutans, one of which reacted with a polyclonal antiserum directed against the FimA fimbrial adhesin from Streptococcus parasanguis on Western blots. The results of Western blot and Northern hybridization experiments support an inverse relationship between iron availability and $S$. mutans fimA expression, and metal ion uptake experiments implicate FimA in S. mutans ${ }^{55} \mathrm{Fe}$ transport. Cloning of the $S$. mutans fimA homologue facilitated the construction of a fimA knockout mutant which grew poorly in an ironlimiting medium relative to the wild-type progenitor strain, lending further support to a role for FimA in S. mutans iron transport. The authors also identified and cloned a dtxR-like gene (dlg) located downstream of fimA on the S. mutans chromosome, and noted increased fimA expression in a S. mutans dlg knockout mutant relative to wild-type on RNA spot blots and Western blots. The uptake of ${ }^{55} \mathrm{Fe}$, which was also significantly increased in this mutant, was compromised in a fimA/d/g double knockout. These findings are consistent with a role for Dlg in the iron-mediated regulation of fimA, and possibly other S. mutans iron transporters. Finally, the cariogenic potential of the fimA and dlg knockout mutants was not significantly different from that of the wild-type progenitor in a germ-free rat model.
\end{abstract}

Keywords: oral streptococci, fim $A, d t x R$, regulation, metals, iron uptake

\section{INTRODUCTION}

Elemental iron is an essential micronutrient for most bacterial pathogens. In the human host, $99.9 \%$ of intracellular iron is bound to ferritin storage proteins or haem compounds (Weinberg, 1978), while extracellular iron is complexed to the carrier proteins transferrin (in serum) and lactoferrin (in mucosal secretions) (Finkelstein et al., 1983). The concentration of free iron in living tissues is only $10^{-12} \mu \mathrm{M}$, however, well below the needs of invading pathogens (Weinberg, 1978). Thus, bacteria experience a shift from high to low iron availability upon entering a mammalian host, which can signal the production of iron-chelating siderophores

Abbreviation: IR, inverted repeat. and/or the synthesis of iron-specific receptors and transport proteins (Wooldridge \& Williams, 1993). In addition, iron limitation can trigger virulence gene expression in invading pathogens.

Despite a well-documented role for iron in promoting the pathogenesis of some Gram-negative microorganisms (Bullen et al., 1978), the involvement of this micronutrient in disease brought on by Gram-positive bacteria has not been extensively investigated. While early epidemiological and clinical studies suggested that certain trace metals in food and drinking water, including iron, may be associated with the development of dental caries (Adkins \& Losee, 1970; Aranha et al., 1982), the mechanism(s) by which iron exerts its putative effect(s) on Streptococucs mutans-induced cariogenesis remain unclear. In previous work, the absence of typical 
hydroxamate- and/or catecholate-like siderophores from $S$. mutans was suggested by biochemical assays specific for these compounds (Evans et al., 1986). In our laboratory, dialysis bag experiments (Husson et al., 1993) conducted in parallel with a universal siderophore detection assay (Schwyn \& Neilands, 1987) have confirmed that $S$. mutans does not elaborate these small iron-chelating molecules (unpublished observations).

FimA is a $36 \mathrm{kDa}$ fimbrial lipoprotein adhesin on the surface of Streptococcus parasanguis (also known as $S$. parasanguinis), the primary colonizer of dental plaque and major player in subacute endocarditis (BurnetteCurley et al., 1995; Viscount et al., 1997). Interestingly, reports in the literature implicate a role for $S$. parasanguis FimA in adherence to fibrin (BurnetteCurley et al., 1995) but not to saliva-coated hydroxyapatite (Froeliger \& Fives-Taylor, 2000). In the present study, we identified a $34 \mathrm{kDa}$ fimA homologue in $S$. mutans.

FimA belongs to the lipoprotein receptor antigen I (LraI) family (Fenno et al., 1995) of proteins, which is transcribed as part of ABC-transporter-type operons. Reports in the literature indicate that in addition to functioning as adhesins, LraI proteins are also involved in metal ion transport (Dintilhac \& Claverys, 1997; Kolenbrander et al., 1998). Among the LraI adhesins previously described in the streptococci are ScaA in $S$. gordonii (Kolenbrander et al., 1994), PsaA and AdcA in S. pneumoniae (Dintilhac et al., 1997), ScbA in S. crista (Correia et al., 1996), SsaB in S. sanguis (also known as $S$. sanguinis) (Ganeshkumar et al., 1991), Lmb in $S$. agalactiae (Spellerberg et al., 1998) and FimA in $S$. parasanguis (Burnette-Curley et al., 1995; Fenno et al., 1995). Of these adhesins, ScaA and PsaA are known to facilitate the transport of manganese ions (Kolenbrander et al., 1998; Dintilhac et al., 1997) while AdcA is reported to be a putative transporter of zinc (Dintilhac et al., 1997). Other studies describe the translocation of metal ions, including iron, by an $\mathrm{ABC}$ transporter lipoprotein in the group A streptococci (Janulcyk et al., 1999). In the present study, we generated a knockout mutation in the $S$. mutans fimA gene to define a putative role for the FimA lipoprotein in iron uptake/transport.

The regulation of iron uptake/transport by the fur gene product is well documented in Gram-negative bacteria such as Escherichia coli, Neisseria gonorrhoeae and Vibrio cholerae (Zimmerman et al., 1984; Fleming et al., 1983; Genco \& Desai, 1996; Butteron et al., 1992), in which Fur- $\mathrm{Fe}^{2+}$ complexes bind to the bacterial chromosome and prevent transcription of iron-dependent genes. Homologues of fur have not been identified in S. mutans. Rather, in the present study we identified a $d t x R$-like gene $(d l g)$ downstream of the fimA operon on the $S$. mutans chromosome for which there is a homologue in Corynebacterium diphtheriae. DtxR in C. diphtheriae is an iron-dependent metalloregulatory protein that complexes with $\mathrm{Fe}^{2+}$ to regulate the expression of diphtheria toxin and other virulence-associated genes (Boyd et al., 1990; Hennecke, 1990; Schmidt, 1997; Schiering et al., 1995). Herein, we present evidence that is consistent with a role for the $S$. mutans DtxR homologue in irondependent regulation of $S$. mutans fimA expression.

\section{METHODS}

Media preparation. A chemically defined FMC medium (Terleckyj et al., 1975) was prepared without magnesium, manganese or iron as previously described (Spatafora \& Moore, 1998). Briefly, the medium was stirred vigorously over $30 \mathrm{~g} \mathrm{l}^{-1}$ Chelex-100 chelating resin (Supelco) for $60 \mathrm{~min}$ at $4{ }^{\circ} \mathrm{C}$ to remove trace metals (the resin was pre-treated to remove fines and residual iminodiacetic acid moieties as described by the manufacturer). The medium was then filtersterilized and amended with $\mathrm{MgSO}_{4}(80 \mu \mathrm{M}), \operatorname{MnSO}_{4}(0 \cdot 4 \mu \mathrm{M})$ and ferric citrate $(1 \cdot 2 \mu \mathrm{M})$ to yield an iron-replete medium. Alternatively, the Chelex-treated medium was supplemented with only $\mathrm{MgSO}_{4}$ and $\mathrm{MnSO}_{4}$ as described above to generate an iron-depleted environment. For expression studies, ferric citrate was added to the iron-depleted medium described above at concentrations ranging from 0.01 to $10 \mu \mathrm{M}$. Absolute metal ion concentrations were confirmed on a Thermo Jarell Ash Inductively Coupled Argon Plasma (ICAP 61) analyser (Coish \& Sinton, 1992) that had been previously standardized with a metal solution containing 1000 p.p.m. iron, magnesium and manganese.

Bacterial culture conditions. Wild-type S. mutans UA130 (serotype $c$ ) was grown overnight at $37^{\circ} \mathrm{C}$ and $5 \% \mathrm{CO}_{2}$ in $14 \mathrm{ml}$ Todd-Hewitt broth (THB). S. mutans GMS700 and GMS800 were grown overnight as described in THB supplemented with kanamycin $\left(250 \mu \mathrm{g} \mathrm{ml}^{-1}\right)$, and GMS850 was grown in THB supplemented with erythromycin $\left(10 \mu \mathrm{g} \mathrm{ml}^{-1}\right)$. Cultures were stored in THB containing $20 \%(\mathrm{v} / \mathrm{v})$ sterile glycerol at $-80^{\circ} \mathrm{C}$.

For growth-curve determinations and Northern hybridization experiments, $S$. mutans was grown at $37^{\circ} \mathrm{C}$ with $5 \% \mathrm{CO}_{2}$ as described, and the cells harvested by centrifugation at 7000 r.p.m. for $10 \mathrm{~min}$ in an SS34 rotor. The cell pellets were washed three times in iron-depleted FMC and resuspended in $1 \mathrm{ml}$ of the same. Fourteen millilitres of FMC containing various concentrations of iron were then inoculated with $150 \mu \mathrm{l}$ of this cell concentrate and grown as described for up to $24 \mathrm{~h}$.

Total RNA for spot blotting was derived from overnight cultures of S. mutans UA130 and GMS800 grown in THB or THB supplemented with kanamycin, respectively. These cultures were used to inoculate $45 \mathrm{ml}$ THB and grown to early-, mid- and late-exponential and stationary phases as described.

Protein isolation and SDS-PAGE. For the preparation of cell lysates, $14 \mathrm{ml}$ volumes of FMC containing $0 \cdot 01-10 \mu \mathrm{M}$ ferric citrate were inoculated, and the cells grown and harvested as described. The cell pellets were resuspended in cold phosphate-buffered saline containing $0.5 \mathrm{mM}$ PMSF and the cell suspensions transferred to microcentrifuge tubes containing $1 / 3$ vol. zirconium beads $(0 \cdot 1 \mathrm{~mm})$. The cells were disrupted in a Mini-Bead Beater (Biospec) at $4{ }^{\circ} \mathrm{C}$ for $3 \mathrm{~min}$ and cellular debris removed by low-speed centrifugation for $1 \mathrm{~min}$ in a refrigerated microcentrifuge. Total protein determinations were performed for each sample using a BCA protein assay kit (Pierce) and bovine serum albumin as a standard. The cell lysates were combined with an equal volume of $2 \times$ sample buffer (Laemmli, 1970) and incubated at room temperature for $2 \mathrm{~h}$ prior to loading onto a 5-15\% SDSPAGE gradient gel. Electrophoresis proceeded at $90 \mathrm{~V}$ for $16 \mathrm{~h}$, followed by staining with Coomassie brilliant blue R-250 (Sigma) and/or silver stain (AMRESCO). 
Table 1. Plasmids

\begin{tabular}{|c|c|c|}
\hline Plasmid & Phenotype & Source* \\
\hline 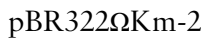 & $4.3 \mathrm{~kb}$ pBR322 with $2 \cdot 0 \mathrm{~kb} \Omega \mathrm{Km}-2$ cassette, $\mathrm{Ap}^{\mathrm{R}} \mathrm{Tc}^{\mathrm{R}} \mathrm{Km}^{\mathrm{R}}$ & M. Caperon \\
\hline pfimEm1 & $\begin{array}{l}\text { pMM1 with an } \mathrm{Em}^{\mathrm{R}} \text { gene inserted in the middle of the } \\
\text { fimA gene, } 5.4 \mathrm{~kb}, \mathrm{Em}^{\mathrm{R}} \mathrm{Ap}^{\mathrm{R}}\end{array}$ & This laboratory \\
\hline pfimEm2 & $4 \cdot 3 \mathrm{~kb}$ pfimEm 1 with $\Delta \mathrm{Ap}^{\mathrm{R}}, \mathrm{Em}^{\mathrm{R}} \mathrm{Ap} \mathrm{p}^{\mathrm{s}}$ & This laboratory \\
\hline pGEMT-EZ & $3 \cdot 0 \mathrm{~kb}$ TA cloning vector, $\mathrm{Ap}^{\mathrm{R}}$ & Promega \\
\hline pMM1 & $\begin{array}{l}\text { pGEMT-EZ vector with } 1.5 \mathrm{~kb} \text { amplicon harbouring } 5^{\prime} \\
\text { end of } S \text {. mutans fimA gene, } \mathrm{Ap}^{\mathrm{R}}\end{array}$ & This laboratory \\
\hline pMM2 & $\begin{array}{l}\text { pMM1 with } \Omega \mathrm{Km}-2 \text { cloned into the fim } A \text { coding } \\
\text { sequence, } 6.6 \mathrm{~kb}, \mathrm{Ap}^{\mathrm{R}} \mathrm{Km}^{\mathrm{R}}\end{array}$ & This laboratory \\
\hline pMM3 & pMM2 with $\Delta \mathrm{Ap}^{\mathrm{R}}, 5 \cdot 5 \mathrm{~kb}, \mathrm{Km}^{\mathrm{R}} \mathrm{Ap}^{\mathrm{S}}$ & This laboratory \\
\hline pSG236 & pVA838-derived, $10 \cdot 26 \mathrm{~kb}, \mathrm{Em}^{\mathrm{R}}$ & S. Goodman \\
\hline pSL1 & $\begin{array}{l}\text { pGEMT-EZ with } 1.4 \mathrm{~kb} \text { amplicon harbouring the } \\
\text { S. mutans dlg gene, } \mathrm{Ap}^{\mathrm{R}}\end{array}$ & This laboratory \\
\hline pSL2 & $\begin{array}{l}\text { pSL1 with } a p h A 3 \text { in } d l g \text { coding sequence, } 5.9 \mathrm{~kb}, \mathrm{Ap}^{\mathrm{R}} \\
\mathrm{Km}^{\mathrm{R}}\end{array}$ & This laboratory \\
\hline pSL3 & pSL2 with $\Delta \mathrm{Ap}^{\mathrm{R}}, 4.8 \mathrm{~kb}, \mathrm{Km}^{\mathrm{R}} \mathrm{Ap}^{\mathrm{S}}$ & This laboratory \\
\hline pVT389 & $\begin{array}{l}6 \cdot 0 \mathrm{~kb} \text { pET } 27 \mathrm{~b} \text { with } \Omega \mathrm{Km}-2 \text { inserted into } S \text {. parasanguis } \\
\text { fap1 gene }\end{array}$ & P. Fives-Taylor \\
\hline
\end{tabular}

* M. Caperon, Dept of Molecular Microbiology, Washington University School of Medicine, St Louis, MO, USA; S. Goodman, Dept of Basic Sciences, University of Southern California School of Dentistry, Los Angeles, CA, USA; P. Fives-Taylor, Dept of Microbiology \& Molecular Genetics, University of Vermont, Burlington, VT, USA.

Western blotting. S. mutans proteins $(50 \mu \mathrm{g}$ per lane) were resolved on each of two SDS-PAGE gels, one of which was stained with Coomassie blue. Proteins from the other gel were transferred electrophoretically to nitrocellulose membranes in a Hoeffer Western transfer apparatus at $0.2 \mathrm{~A}$ and $4{ }^{\circ} \mathrm{C}$ overnight. The membrane was blocked in $100 \mathrm{ml} 5 \%$ (w/v) powdered skim milk for $1 \mathrm{~h}$ with gentle agitation, washed twice in $100 \mathrm{ml}$ Tris-buffered saline/Tween for $10 \mathrm{~min}$ each, and then allowed to react with a 1:5000 dilution of a polyclonal rabbit antiserum directed against FimA from $S$. parasanguis (provided by Dr Paula Fives-Taylor, University of Vermont). Following three additional washes as described, a 1:10000 dilution of a horseradish-peroxidase-conjugated goat anti-rabbit antiserum (Sigma or Pierce) was applied. After several more washes, the blots were prepared for visualization by enhanced chemiluminescence (ECL) according to the manufacturer's recommendations (Amersham Life Science).

Cloning of the $S$. mutans fimA gene and construction of a fimA knockout mutation. The primers and plasmids used to clone and subsequently disrupt the $S$. mutans fimA gene are shown in Tables 1 and 2. The $5^{\prime}$ end of the S. mutans fimA gene was amplified with primers SmfimA-F and SmfimA-R using sequence information derived from the GenBank database (accession number AF232688) and cloned into pGEMTEZ (Promega) according to the recommendations of the supplier. The resulting recombinant, pMM1, includes a unique HindIII site 13 bp downstream of the fimA initiation codon which we exploited in subsequent knockout mutagenesis experiments. Specifically, a $2 \cdot 0 \mathrm{~kb} \Omega \mathrm{Km}-2$ kanamycinresistance cassette $(a p h A 3 \Omega$ ) from plasmid pBR322Km $\Omega$ was cloned into the HindIII site within the fimA coding sequence on pMM1, and E. coli transformants harbouring the fimA knockout mutation were selected on L-agar supplemented with kanamycin $\left(50 \mu \mathrm{g} \mathrm{ml}^{-1}\right)$. The knockout mutation was confirmed by sequence analysis of plasmid DNA isolated and purified on mini-prep spin columns (Qiagen). We disrupted the ampicillin-resistance gene resident on the resulting pMM2 construct with $P v u \mathrm{I}$, and recircularized the $5.5 \mathrm{~kb}$ fragment with $\mathrm{T}_{4}$ DNA ligase (Promega) following gel extraction (Qiagen). Plasmid DNA (pMM3) was isolated from E. coli transformants demonstrating resistance to kanamycin, and confirmed by restriction enzyme mapping. To confirm ampicillin sensitivity, transformants were also replica-plated onto L-agar supplemented with $50 \mu \mathrm{g}$ ampicillin $\mathrm{ml}^{-1}$. Finally, pMM3 was moved into $S$. mutans by electroporation (Spatafora et al., 1995), and the double crossover event selected for on Todd-Hewitt agar (TH agar) plates supplemented with kanamycin $\left(250 \mu \mathrm{g} \mathrm{ml}^{-1}\right)$. The resulting $S$. mutans knockout mutant (GMS700) was confirmed by Southern blot analysis of restricted chromosomal DNA isolated as described by Sambrook et al. (1989). A DNA fragment internal to the fimA coding sequence was generated using primers fimA.pb-F and fimA.pb-R and radiolabelled for hybridization experiments.

Cloning of the S. mutans $\mathbf{d l g}$ gene and construction of a $\mathrm{dlg}$ knockout mutation. The primers and plasmids used to clone and disrupt the $S$. mutans $d l g$ gene are shown in Tables 1 and 2. The $S$. mutans $d l g$ gene was amplified with primers Sm-dlg$\mathrm{F}$ and $\mathrm{Sm}$-dlg-R using sequence information derived from the GenBank database (accession number AF232688) and cloned as a $1.4 \mathrm{~kb}$ amplicon into pGEMT-EZ (Promega) according to the recommendations of the supplier. A unique BstZ17-I site located $456 \mathrm{bp}$ downstream of the $d l g$ start codon on the resulting recombinant, pSL1, served as the insertion site for a $1.5 \mathrm{~kb}$ aphA3 kanamycin-resistance cassette. The cassette was amplified from plasmid pVT389 using primers aphA3BstZ17I-F and aphA3-BstZ17I-R, and the resulting amplicon was digested with BstZ17I to generate blunt ends. The cassette was then ligated into the $d l g$ coding region, and E. coli transformants harbouring the $d l g$ knockout mutation were selected on L-agar plates supplemented with kanamycin 
Table 2. Primers

Restriction sites are underlined.

\begin{tabular}{|ll|}
\hline Primer & \multicolumn{1}{c|}{ Sequence $\left(\mathbf{5}^{\prime} \mathbf{- 3}^{\prime}\right)$} \\
\hline SmFimA-F & GCAGCGGGTTCAAGCATTGTC \\
SmFimA-R & CAGCTGGGAGTAGGCGGAAACC \\
fimA.pb-F & CGCTGGTAATAAGGTTGTC \\
fimA.pb-R & CATTGTGACAGACCATTTGC \\
Sm-dlg-F & GGCTTACGATATTCCTTCT \\
Sm-dlg-R & GTTCGTGAATTTCGTGGC \\
Sm-dlg-pb-F & CTGCTCCGGCTGTCTCAG \\
Sm-dlg-pb-R & CAGTGGCAACTGCTGATGT \\
aphA3-BstZ17I-F & CAGCGAGTATACCACCTGCCCAGTCACGACGTTGTAAAA \\
aphA3-BstZ17I-R & GGGGTGGTATACGGCAGCGGATAACAATTTCACACAGG \\
ermAMHin-F & CCCAAGCTTGGGGCGGAAACGTAAAAGAAG \\
ermAMHin-R & CCCAAGCTTGGGGAAGCTGTCAGTAGTATACC \\
rpsL-F & GAATGTAGATGCCTACAATTAACCA \\
rpsL-R & TTTACGACTCATTTCTCTTTATCCC \\
\hline
\end{tabular}

$\left(50 \mu \mathrm{g} \mathrm{ml}^{-1}\right)$. The resulting recombinant, pSL2, was isolated and digested with PvuI as described to disrupt ampicillin resistance, and a $4.7 \mathrm{~kb}$ fragment was gel-purified (Qiagen) and recircularized with $T_{4}$ DNA ligase (Promega). The final construct, pSL3, was isolated from E. coli transformants demonstrating kanamycin-resistance and sensitivity to ampicillin according to Qiagen protocols, and confirmed by restriction enzyme mapping. Plasmid pSL3 was then electroporated into $S$. mutans, and the $d l g$ knockout mutation on the chromosome selected for on TH agar containing $250 \mu \mathrm{g}$ kanamycin $\mathrm{ml}^{-1}$. The double-crossover event was confirmed by PCR and Southern blot analysis, and the resulting mutant was called GMS800.

Construction of GMS850, a $S$. mutans fimA/dlg double knockout mutant. Primers ermAMHin-F and ermAMHin-R (Table 2) were used to amplify an erythromycin-resistance determinant (ermAM) from plasmid pSG236 (Goodman \& Gao, 2000). The resulting $0.94 \mathrm{~kb}$ amplicon was digested with HindIII and ligated into the HindIII site located within the fim $A$ coding sequence cloned on plasmid pMM1. E. coli transformants were selected on L-agar supplemented with $300 \mu \mathrm{g}$ erythromycin $\mathrm{ml}^{-1}$ from which putative recombinants (pfimEm1) were isolated and purified on Qiagen spin columns. The pfimEm 1 construct was confirmed by restriction mapping, and digested with PvuI to disrupt the ampicillin-resistance gene on the plasmid. The resulting construct, pfimEm2, was subsequently used to transform the $S$. mutans $d l g$ knockout mutant (GMS800) as described. Streptococcal transformants demonstrating resistance to both erythromycin $\left(10 \mu \mathrm{g} \mathrm{ml}^{-1}\right)$ and kanamycin $\left(250 \mu \mathrm{g} \mathrm{ml}^{-1}\right)$ on TH agar plates were selected for Southern blot analysis to confirm knockout mutations in the fim $A$ and $d l g$ genes on the $S$. mutans chromosome (data not shown).

DNA isolation. Chromosomal DNA was isolated from $S$. mutans UA130, GMS700, GMS800 and GMS850 using a modification of the method of Marmur (1961). The DNA was purified by caesium chloride/ethidium bromide equilibrium density-gradient centrifugation and digested with restriction enzymes (Promega) according to the recommendations of the supplier. Plasmid DNA was extracted and purified from E. coli transformants using Qiagen spin columns (Qiagen).
PCR. Primers used to generate amplicons for cloning and/or nick translation are shown in Table 2. Amplification with Red Taq polymerase (Sigma) was performed in a Hybaid PCR Express thermocycler with the following cycling conditions: $94{ }^{\circ} \mathrm{C}$ for $1 \mathrm{~min}, 50{ }^{\circ} \mathrm{C}$ for $2 \mathrm{~min}$ and $72{ }^{\circ} \mathrm{C}$ for $2 \mathrm{~min}$ repeated for 35 cycles, followed by a $72^{\circ} \mathrm{C}$ extension for $10 \mathrm{~min}$.

Southern blotting. Restricted chromosomal DNAs from $S$. mutans UA130, GMS700 and GMS850, or from PCR products generated as described above, were resolved on $0.8 \%$ agarose gels and transferred to nitrocellulose membranes according to the method of Southern (1975). The DNAs were cross-linked to the membranes in a FisherBrand cross-linker (FB-UVXL1000 ) and probed with a $770 \mathrm{bp}$ fimA-specific or a $500 \mathrm{bp} d \mathrm{lg}$ specific amplicon that had been previously radiolabelled with $\left[{ }^{32} \mathrm{P}\right] \mathrm{dATP}$ by nick translation (Rigby et al., 1977). Primers fimA.pb-F and fimA.pb-R or Sm-dlg-pb-F and Sm-dlg-pb-R (Table 2) were used to amplify the fimA- or $d l g$-specific probes, respectively. Filters were hybridized in $1 \%$ BSA, $300 \mathrm{mM}$ sodium phosphate, $7 \%$ SDS and $100 \mathrm{mM}$ EDTA, $\mathrm{pH} 8$, at $60^{\circ} \mathrm{C}$ for $16 \mathrm{~h}$ in a FisherBrand hybridization oven with gentle agitation. The membranes were then washed once for $10 \mathrm{~min}$ at $60^{\circ} \mathrm{C}$ in $0.5 \% \mathrm{BSA}, 40 \mathrm{mM}$ sodium phosphate, $5 \%$ SDS and $1 \mathrm{mM}$ EDTA, and twice for $10 \mathrm{~min}$ each at $60^{\circ} \mathrm{C}$ in $40 \mathrm{mM}$ sodium phosphate, $1 \%$ SDS and $1 \mathrm{mM}$ EDTA. Autoradiography (Kodak BIOMAX ML film) proceeded for up to $24 \mathrm{~h}$ at $-80^{\circ} \mathrm{C}$ in the presence of an intensifying screen.

RNA isolation. For Northern hybridization experiments, total intact RNA was isolated from $S$. mutans UA130 cultures grown as described in FMC supplemented with $0 \cdot 01-10 \mu \mathrm{M}$ ferric citrate. The cultures were centrifuged at $4{ }^{\circ} \mathrm{C}$ and 6000 r.p.m. in an SS34 rotor for $5 \mathrm{~min}$ and the cell pellets resuspended in $4 \mathrm{ml}$ ice-cold sterile Tris/EDTA (TE) buffer, $\mathrm{pH} 8 \cdot 0$. To the cell suspensions, $3.5 \mathrm{~g}$ sterile, chilled, acidwashed glass beads (Sigma, 150-220 $\mu \mathrm{m}$ diameter) were added and immediately mixed with $3 \mathrm{ml}$ phenol/chloroform/ isoamyl alcohol (PCI), $\mathrm{pH} 4 \cdot 3$ (Sigma). After the addition of $0.25 \mathrm{ml} 10 \%$ SDS, the mixture was vortexed for $4 \mathrm{~min}$ with intermittent cooling on ice. The cell mixture was then centrifuged as described above and the aqueous phase extracted three more times with PCI, pH 4.3. Nucleic acid was 
precipitated overnight at $-20{ }^{\circ} \mathrm{C}$ in the presence of $0 \cdot 1$ vol. $10 \mathrm{M} \mathrm{LiCl}$ and 2 vols ethanol. The RNA was pelleted by centrifugation at 8000 r.p.m. and $4{ }^{\circ} \mathrm{C}$ in an SS34 rotor for $15 \mathrm{~min}$ and subsequently washed in ice-cold $70 \%$ ethanol. Finally, the RNA pellets were air-dried, resuspended in $50 \mu \mathrm{l}$ sterile diethyl pyrocarbonate-treated water, and stored frozen at $-80^{\circ} \mathrm{C}$. For spot blot hybridization studies, total RNA was isolated from $S$. mutans by disruption in a reciprocating shaking device (FastPrep, Bio101) according to the Bio101 Fast RNA Blue protocol.

Northern and spot blots. Total RNA isolated from UA130 and GMS700 was resolved on a $0.8 \%$ formaldehyde agarose gel, transferred to a nitrocellulose membrane, and crosslinked in a FisherBrand cross-linker. Spot blots of total RNA isolated from GMS800 were prepared using a Schleicher and Schuell Minifold I apparatus according to the recommendations of the supplier. RNAs were probed with a radiolabelled $770 \mathrm{bp}$ amplicon that is internal to the fim $\mathrm{A}$ coding sequence, or (as an internal control) with a $500 \mathrm{bp} r p s L$ amplicon derived from the $S$. mutans chromosome using primers rpsL-F and rpsL-R (Table 2 ). Hybridization and wash conditions were as described for Southern blotting.

Metal ion uptake. S. mutans UA130, GMS700, GMS800 and GMS850 were grown overnight in THB with $250 \mu \mathrm{g}$ kanamycin $\mathrm{ml}^{-1}$ or $10 \mu \mathrm{g}$ erythromycin $\mathrm{ml}^{-1}$ when appropriate. The precultures $(250 \mu \mathrm{l})$ were used to inoculate $50 \mathrm{ml}$ prewarmed THB and grown to early exponential phase. Then $7 \cdot 4 \times 10^{4} \mathrm{~Bq}^{55} \mathrm{FeCl}_{3}(3 \mu \mathrm{M})$ or ${ }^{54} \mathrm{MnCl}_{2}(0.03 \mu \mathrm{M})$ was added to $1 \mathrm{ml}$ cells and the cultures were grown overnight as described. The bacteria were pelleted and washed three times in fresh THB, and radioactivity was measured in a scintillation counter calibrated for ${ }^{55} \mathrm{Fe}$ or ${ }^{54} \mathrm{Mn}$. Control cultures grown in parallel and in the absence of radioisotope were serially diluted and plated on TH agar plates for bacterial enumeration.

Cariogenic potential of S. mutans GMS700 and GMS800 in germ-free rats. The cariogenic potential of $S$. mutans UA130, GMS700 and GMS800 was determined in young gnotobiotic Fischer rats. Nineteen-day-old weanling rats were challenged orally with approximately $10^{8}$ c.f.u. $\mathrm{ml}^{-1}$ of the appropriate test strain. Animals were maintained on a sterile cariespromoting diet containing $5 \%$ sucrose (Michalek et al., 1975) provided ad libitum. Colonization was assessed $2 \mathrm{~d}$ postchallenge and then weekly for the duration of the experiment by collecting faecal swab samples and culturing them on Mitis Salivarius (MS) agar (Difco) with or without kanamycin. Rats killed 35 d post-challenge were scored for caries (Keyes, 1958), and plaque microbiology was assessed on MS agar with appropriate selection to confirm the presence of UA130, GMS700 or GMS800.

Statistical analysis. Means and standard errors for caries scores and bacterial metal ion uptake were evaluated by analysis of variance using the Duncan and Kruskal-Wallis tests, respectively. Differences were considered to be significant at $P \leqslant 0 \cdot 05$.

\section{RESULTS}

\section{S. mutans UA130 requires iron for optimal growth}

We monitored the growth of $S$. mutans UA130 in ferric citrate-depleted vs replete FMC medium and noted that growth was compromised in the former (Fig. 1). Similar results were obtained from $S$. mutans cultures grown in Chelex-treated FMC supplemented with ferric chloride

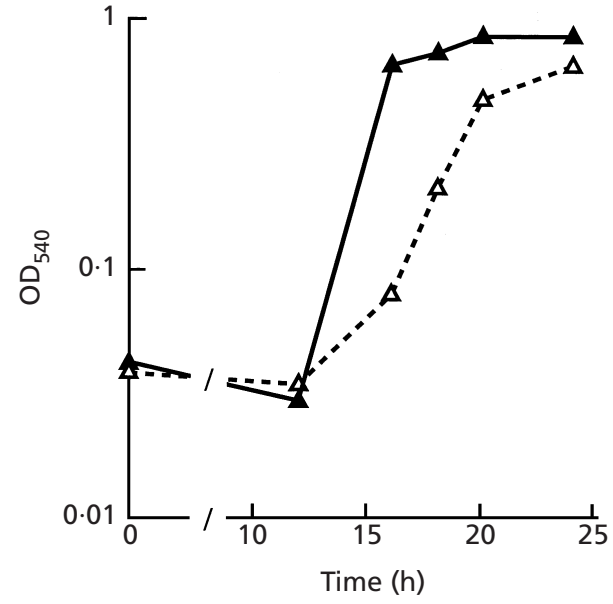

Fig. 1. S. mutans requires iron for optimal growth. S. mutans UA130 was grown for up to $24 \mathrm{~h}$ in Chelex-treated FMC containing $1.2 \mu \mathrm{M}$ (filled triangles) or $0.4 \mu \mathrm{M}$ (open triangles) ferric citrate prepared as described in Methods. The data indicate that $S$. mutans requires iron for optimal growth. $\mathrm{OD}_{540}$ measurements were obtained in a Genosys 2 spectrophotometer. Growth curve experiments were performed in triplicate. The results of a single representative experiment are shown.

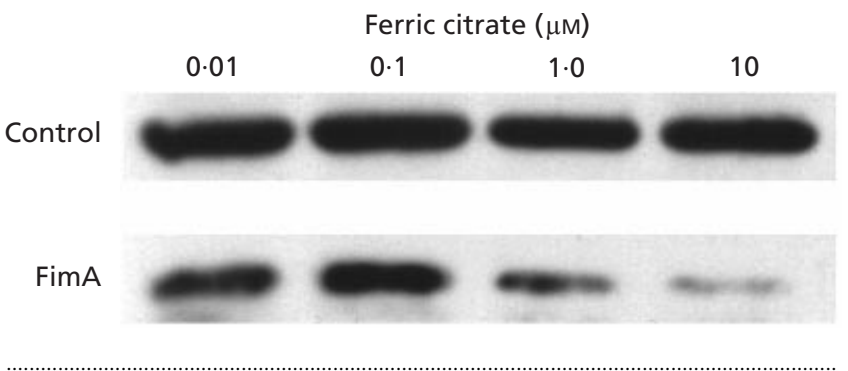

Fig. 2. Expression of $S$. mutans FimA is iron responsive. $S$. mutans proteins ( $50 \mu \mathrm{g}$ per lane) isolated from UA130 cultures grown in FMC containing 0.01-10 $\mu \mathrm{M}$ ferric citrate and resolved on a $12.5 \%$ SDS-PAGE gel were reacted on a Western blot with a polyclonal antiserum directed against the $36 \mathrm{kDa}$ FimA lipoprotein from S. parasanguis. A $34 \mathrm{kDa}$ FimA protein reacted with this antiserum, the expression of which decreased as iron concentration increased. A secondary antiserum (Sigma) that cross-reacts non-specifically with a constitutively expressed protein of $48 \mathrm{kDa}$ was applied in this experiment to provide an internal control against which fimA expression could be quantified (see Table 3).

(data not shown). Together these findings support iron as an essential micronutrient for the optimal growth of S. mutans.

\section{SDS-PAGE and Western blot analysis of S. mutans UA130}

Protein profiles derived from $S$. mutans UA130 whole cells grown in FMC supplemented with $0 \cdot 01-10 \mu \mathrm{M}$ ferric citrate revealed decreased expression of several proteins with increasing iron concentration (unpublished observations). In particular, immunoblots of $S$. mutans whole-cell lysates reacted with a polyclonal 
Table 3. Effect of ferric citrate on S. mutans FimA expression

\begin{tabular}{|llcc|}
\hline \multirow{2}{*}{$\begin{array}{l}\text { Ferric citrate } \\
\text { concn }(\boldsymbol{\mu M})\end{array}$} & \multicolumn{3}{c|}{ Absorbance units* } \\
\cline { 2 - 4 } & FimA & Control & Ratio $\dagger$ \\
\hline $0 \cdot 01$ & $1 \cdot 6$ & $2 \cdot 6$ & $0 \cdot 62$ \\
$0 \cdot 1$ & $2 \cdot 6$ & $2 \cdot 8$ & $0 \cdot 93$ \\
$1 \cdot 0$ & $0 \cdot 85$ & $2 \cdot 2$ & $0 \cdot 39$ \\
10 & $0 \cdot 15$ & $2 \cdot 3$ & $0 \cdot 07$ \\
\hline
\end{tabular}

* Measured on Western blots (see Fig. 2) with an LKB ULTRASCAN XL laser densitometer.

† Ratio of FimA to control protein expression.

antiserum directed against the $S$. parasanguis FimA lipoprotein revealed a 10-fold decrease in expression for the $34 \mathrm{kDa}$ S. mutans FimA homologue as ferric citrate concentrations increased (see Fig. 2 and Table 3).

\section{Northern blot analysis}

To determine whether iron-responsive FimA expression in $S$. mutans is regulated at the level of transcription, we isolated total RNA from UA130 grown in Chelextreated FMC containing $0.01 \mu \mathrm{M}$ or $10 \mu \mathrm{M}$ ferric citrate. The RNAs were resolved on $0.8 \%$ formaldehyde agarose gels, transferred to nitrocellulose membranes, and hybridized with a 770 bp fimA-specific amplicon which is internal to the $S$. mutans fimA coding region. The resulting Northern blot revealed decreased expression of the $S$. mutans fimA gene at the higher iron concentration (data not shown).

\section{Cloning of the $S$. mutans fimA gene and confirmation of a fimA knockout mutation in S. mutans GMS700}

The strategy used to clone and interrupt the $S$. mutans fim A coding sequence in E. coli is illustrated in Fig. 3(a). The $\Omega \mathrm{Km}-2$ cassette $(a p h A 3 \Omega$ ) resident on pMM 3 was then used to disrupt the wild-type fimA gene on the $S$. mutans UA130 chromosome by allelic exchange. The resulting knockout mutation in GMS700 was confirmed by Southern blot using a $770 \mathrm{bp}$ fimA-specific probe. Insertion of the $1.8 \mathrm{~kb} \Omega \mathrm{Km}-2$ cassette into the fim $A$ coding sequence on the GMS700 chromosome is supported by a shift in the fimA-containing DNA fragment from $2.6 \mathrm{~kb}$ in UA130 to $4.4 \mathrm{~kb}$ in GMS700 (Fig. 3b).

\section{Cloning of the $S$. mutans dlg gene and confirmation of a dlg knockout mutation in S. mutans GMS800}

The strategy used to clone and disrupt the $S$. mutans $d l g$ gene in E. coli is illustrated in Fig. 4(a). A non-polar aphA3 kanamycin-resistance cassette resident on pSL-3 was used to interrupt the wild-type $d l g$ gene on the $S$. mutans UA130 chromosome by allelic exchange. The resulting knockout mutation in GMS800 was confirmed by PCR using $d l g$-specific primers, and then by Southern
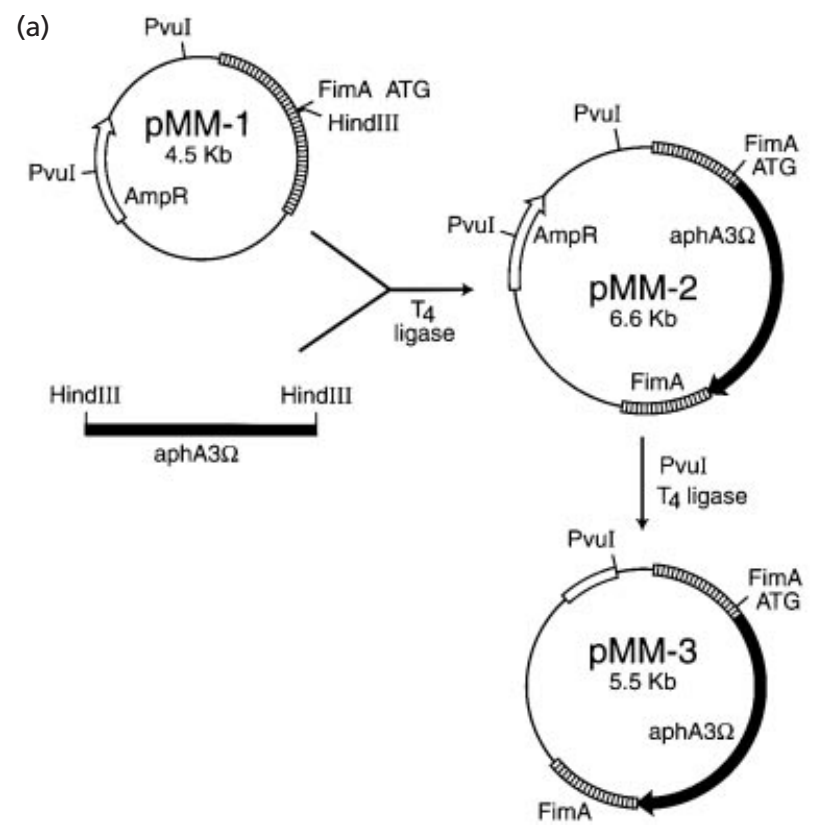

(b)

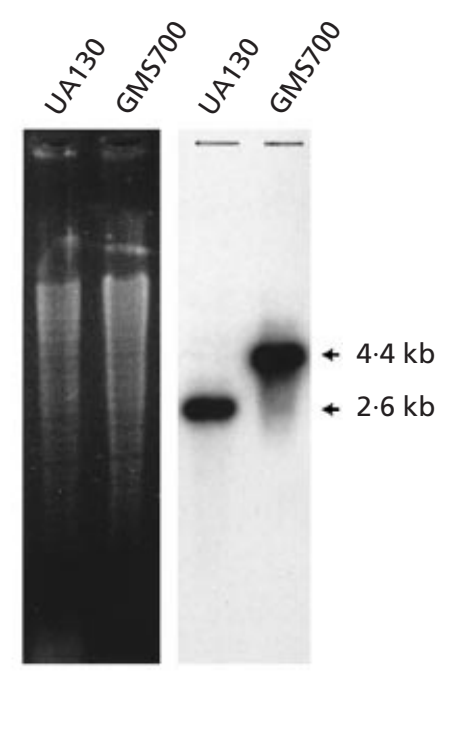

Fig. 3. (a) Strategy used to construct a knockout mutation in the cloned S. mutans fimA gene. (b) Confirmation of the fimA knockout mutation in S. mutans GMS700. Left panel: chromosomal DNA isolated from UA130 and GMS700 was digested with EcoRl and resolved on an $0.8 \%$ agarose gel. Right panel: the restricted DNA was transferred to nitrocellulose, where it was probed for fimA with a $770 \mathrm{bp}$ radiolabelled amplicon. The DNA fragment that hybridizes to the fimA-specific probe is $1.8 \mathrm{~kb}$ larger in GMS700 than in UA130. This is due to the insertion of the $\Omega \mathrm{Km}-2 \mathrm{kanamycin}$ resistance cassette (aphA3 $\Omega$ ) at the fimA locus in GMS700. 
(a)

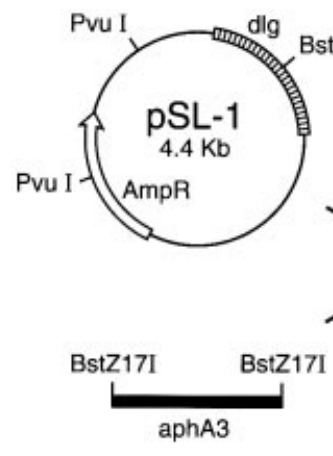

(b)

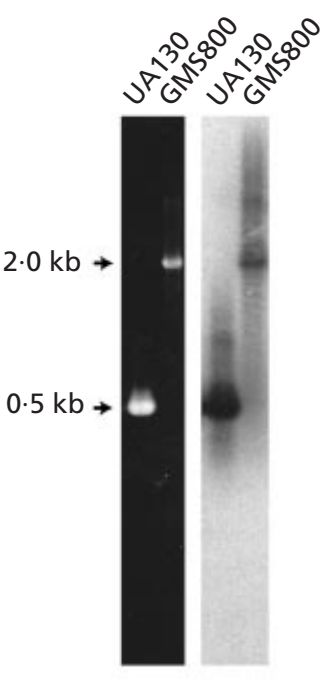

Fig. 4. (a) Strategy used to construct a knockout mutation in the cloned S. mutans dlg gene. (b) Confirmation of the dlg knockout mutation in S. mutans GMS800. Left panel: the dlg gene was PCR-amplified from UA130 and GMS800 using dlg-specific primers, resolved on a $0.8 \%$ agarose gel and stained with ethidium bromide. The amplicon derived from GMS800 is $1.5 \mathrm{~kb}$ larger than that derived from UA130, owing to the successful insertion of an aphA3 kanamycinresistance cassette. Right panel: the DNA from the PCR gel was transferred to nitrocellulose and probed for dlg with a $500 \mathrm{bp}$ radiolabelled amplicon internal to the coding region of the gene. The DNA fragment that hybridizes to the dlgspecific probe is $1.5 \mathrm{~kb}$ larger in GMS800 than in UA130, owing to the insertion of the aphA3 kanamycin-resistance cassette into the $d / g$ coding region.

blotting using a radiolabelled $0.5 \mathrm{~kb}$ probe which is internal to the $d l g$ coding region. The insertion of the $1.5 \mathrm{~kb}$ aph $A 3$ cassette into the $d l g$ coding sequence on the GMS800 chromosome is supported by a shift in the $d l g$-containing DNA fragment from $0.5 \mathrm{~kb}$ in UA130 to $2.0 \mathrm{~kb}$ in the $d l g$ knockout mutant (Fig. 4b).

\section{Confirmation of S. mutans GMS850, a fimA/dlg double knockout mutant}

Knockout mutations in the fim $A$ and $d l g$ genes on the $S$. mutans GMS850 chromosome were confirmed by Southern blot analysis. Specifically, BamHI- and BglIIrestricted chromosomal DNAs from UA130 and GMS850 were resolved on a $0.8 \%$ agarose gel and transferred to a nitrocellulose membrane which was subsequently hybridized with a $770 \mathrm{bp} \mathrm{fimA-specific}$ probe. The probe hybridized to a $5.5 \mathrm{~kb}$ DNA fragment in the UA130 digest and to a $1.5 \mathrm{~kb}$ fragment in GMS850, owing to single BamHI sites present in the ermAM and aphA3 cassettes. This hybridization pattern confirmed the disruption of the fimA and $d l g$ genes on the GMS850 chromosome (data not shown).

\section{Spot blot analysis}

Total RNA isolated from S. mutans UA130 and GMS800 grown in THB was spotted onto a nitrocellulose membrane and hybridized with a fimA-specific probe. The data revealed increased fim $A$ expression in the $d l g$

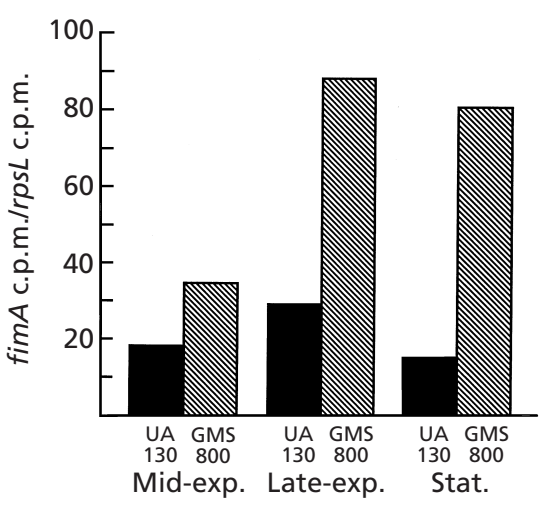

Fig. 5. Expression of fimA is increased in S. mutans GMS800 on RNA spot blots. Total RNA was isolated from S. mutans UA130 and GMS800 as described and spot blotted onto a nitrocellulose membrane for hybridization with a fimA-specific or an $r p s L$ specific probe. The rpsL gene, which encodes a constitutively expressed ribosomal protein (Federle et al., 1999), was used as an internal control to normalize comparisons of fimA expression across samples. Expression of fimA was quantified by scintillation counting and is represented as a proportion of the expression of rpsL. Expression studies were performed in duplicate. The results of a single representative experiment are shown.

mutant relative to the UA130 progenitor during the midexponential, late-exponential and stationary phases of growth (Fig. 5). 


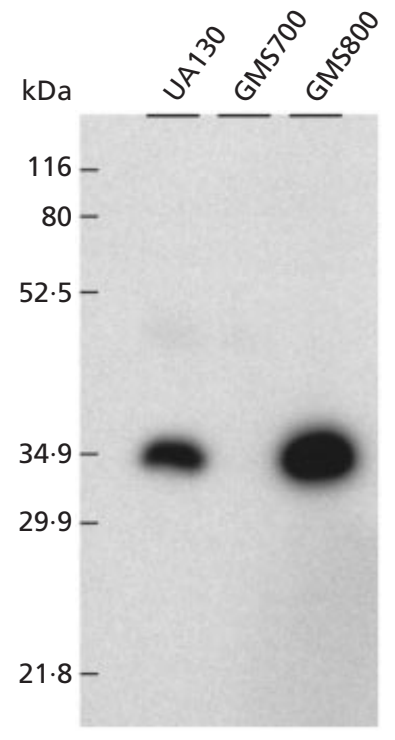

Fig. 6. Expression of FimA is increased in S. mutans GMS800 on Western blots. Whole-cell protein isolated from $S$. mutans UA130, GMS700 and GMS800 grown in THB was resolved on a $12.5 \%$ SDS-PAGE gel $(50 \mu \mathrm{g}$ per lane), transferred to nitrocellulose, and reacted with a polyclonal antiserum directed against the FimA protein from $S$. parasanguis. The resulting Western blot confirms the absence of the $34 \mathrm{kDa}$ FimA protein from the GMS700 fimA knockout mutant, and reveals increased expression of FimA in the GMS800 dlg mutant relative to the UA130 wild-type strain.

\section{Western blot analysis of S. mutans fimA and dlg mutants}

Whole-cell protein ( $50 \mu \mathrm{g}$ per lane) isolated from $S$. mutans UA130, GMS700 and GMS800 grown in THB was resolved on $12.5 \%$ SDS-PAGE gels and reacted with a polyclonal antiserum directed against the $S$. para- sanguis FimA protein as described in Methods. The resulting immunoblot (Fig. 6) confirms the absence of the $34 \mathrm{kDa}$ FimA protein from GMS700 and reveals increased FimA expression in the GMS800 dlg mutant relative to wild-type.

\section{Uptake of ${ }^{55} \mathrm{Fe}$ and ${ }^{54} \mathrm{Mn}$ by S. mutans}

S. mutans UA130, GMS700 and GMS800 were compared for ${ }^{55} \mathrm{Fe}$ and ${ }^{54} \mathrm{Mn}$ transport in metal ion uptake assays. The bacteria were grown overnight in the presence of ${ }^{55} \mathrm{Fe}$ or ${ }^{54} \mathrm{Mn}$, washed repeatedly in fresh THB, and the radioactivity associated with bacterial cell pellets measured in a scintillation counter and expressed as a ratio of c.p.m. per c.f.u. Interestingly, uptake of ${ }^{55} \mathrm{Fe}$ by the GMS700 fimA knockout mutant was not significantly different from that of the UA130 wild-type progenitor $(2 \cdot 7 \pm 0 \cdot 03$ c.p.m. per c.f.u. vs $2 \cdot 3 \pm 0 \cdot 12$ c.p.m. per c.f.u., respectively), possibly owing to other active iron transporters in $S$. mutans. However, we noted significantly increased ${ }^{55} \mathrm{Fe}$ uptake in the GMS800 dlg knockout mutant relative to wild-type, $(6.0 \pm 1 \cdot 0$ c.p.m. per c.f.u. vs $2 \cdot 3 \pm 0 \cdot 12$ c.p.m. per c.f.u., respectively; $P<0.05)$ which was compromised in the GMS850 fimA/dlg double knockout mutant $(4 \cdot 7 \pm 0.60$ c.p.m. per c.f.u. vs $6 \cdot 0 \pm 1 \cdot 0$ c.p.m. per c.f.u.). This finding is consistent with a role for FimA in $S$. mutans iron transport. In contrast, ${ }^{54} \mathrm{Mn}$ uptake was not significantly affected by mutations in fim $A$ or $d l g$ (data not shown), indicating that neither FimA nor Dlg is likely to be involved in the transport of manganese by S. mutans.

\section{S. mutans fimA and dlg knockout mutations do not significantly affect caries formation in vivo}

The cariogenic potential of S. mutans GMS700 and GMS800 was examined in germ-free rats. The results of these experiments are summarized in Table 4 . The mean

Table 4. Cariogenic potential of S. mutans fimA (GMS700) and dlg (GMS800) knockout mutants in germ-free rats

Rats were provided a diet containing $5 \%$ sucrose (diet 305) and killed on experimental day 35 (when $55 \mathrm{~d}$ old). Values are means \pm SEM. Mean caries scores are the extent of caries activity on molar surfaces involving enamel (E), dentinal slight (Ds), dentinal moderate $(\mathrm{Dm})$ and dentinal extensive $(\mathrm{Dx})$ lesions. Bacteria were enumerated on Mitis Salivarius (MS) agar plates.

\begin{tabular}{|c|c|c|c|c|c|c|c|c|c|c|c|c|c|c|c|c|}
\hline \multirow{3}{*}{$\begin{array}{l}\text { Infecting } \\
\text { strain } \\
\text { (group) }\end{array}$} & \multirow{3}{*}{$\begin{array}{l}\text { No. of } \\
\text { rats }\end{array}$} & \multirow{3}{*}{$\begin{array}{c}\text { Weight } \\
(\mathrm{g})\end{array}$} & \multirow{2}{*}{\multicolumn{2}{|c|}{$\begin{array}{c}10^{-4} \times \text { Plaque } \\
\text { bacteria } \\
\text { (c.f.u. } \mathrm{ml}^{-1} \text { ) }\end{array}$}} & \multicolumn{12}{|c|}{ Mean caries score } \\
\hline & & & & & \multicolumn{4}{|c|}{ Buccal } & \multicolumn{4}{|c|}{ Sulcal } & \multicolumn{4}{|c|}{ Proximal } \\
\hline & & & MS & MS + Kan & $\mathrm{E}$ & Ds & $\mathrm{Dm}$ & Dx & E & Ds & $\mathrm{Dm}$ & Dx & E & Ds & $\mathrm{Dm}$ & Dx \\
\hline $\begin{array}{l}\text { S. mutans } \\
\text { UA130 } \\
\text { (group A) }\end{array}$ & 7 & $157 \pm 9$ & $3380 \cdot 0 \pm 1047 \cdot 8$ & $1 \cdot 3 \pm 0 \cdot 5$ & $17 \cdot 6 \pm 0 \cdot 9$ & $15 \cdot 1 \pm 0 \cdot 7$ & $11 \cdot 9 \pm 0 \cdot 6$ & $9 \cdot 3 \pm 0 \cdot 9$ & $20 \cdot 6 \pm 0 \cdot 5$ & $17 \cdot 9 \pm 0 \cdot 4$ & $12 \cdot 4 \pm 0 \cdot 5$ & $7 \cdot 4 \pm 1 \cdot 0$ & $4 \cdot 4 \pm 0 \cdot 7$ & $0 \cdot 0 \pm 0 \cdot 0$ & $0 \cdot 0 \pm 0 \cdot 0$ & $0 \cdot 0 \pm 0 \cdot 0$ \\
\hline $\begin{array}{l}\text { S. mutans } \\
\text { GMS700 } \\
\text { (group B) }\end{array}$ & 7 & $142 \pm 8$ & $2162 \cdot 9 \pm 406 \cdot 3$ & $1984 \cdot 6 \pm 362 \cdot 9$ & $15 \cdot 1 \pm 0 \cdot 6$ & $13 \cdot 1 \pm 0 \cdot 6$ & $9 \cdot 1 \pm 0 \cdot 6$ & $6 \cdot 0 \pm 0 \cdot 7$ & $21 \cdot 1 \pm 0 \cdot 3$ & $17 \cdot 9 \pm 0 \cdot 3$ & $11 \cdot 7 \pm 0 \cdot 3$ & $6 \cdot 3 \pm 0 \cdot 4$ & $4 \cdot 9 \pm 0 \cdot 7$ & $0 \cdot 0 \pm 0 \cdot 0$ & $0 \cdot 0 \pm 0 \cdot 0$ & $0 \cdot 0 \pm 0 \cdot 0$ \\
\hline $\begin{array}{l}\text { S. mutans } \\
\text { GMS800 } \\
\text { (group C) }\end{array}$ & 7 & $140 \pm 10$ & $77 \cdot 4 \pm 41 \cdot 4$ & $71 \cdot 4 \pm 41 \cdot 1$ & $19 \cdot 9 \pm 0 \cdot 9$ & $17 \cdot 6 \pm 0 \cdot 9$ & $14 \cdot 1 \pm 0 \cdot 9$ & $10 \cdot 9 \pm 1 \cdot 5$ & $22 \cdot 6 \pm 0 \cdot 7$ & $20 \cdot 4 * \pm 0 \cdot 4$ & $14 \cdot 1 \pm 0 \cdot 6$ & $8 \cdot 9 \pm 0 \cdot 9$ & $5 \cdot 3 \pm 0 \cdot 7$ & $1 \cdot 6 \pm 0 \cdot 6$ & $0 \cdot 3 \pm 0 \cdot 3$ & $0 \cdot 0 \pm 0 \cdot 0$ \\
\hline
\end{tabular}

* Caries score significantly different $(P \leqslant 0 \cdot 05)$ between groups A and C. 
caries scores for rats infected with either knockout mutant were not significantly different from those infected with the wild-type UA130 progenitor.

\section{DISCUSSION}

With the known exceptions of Lactobacillus plantarum (Archibald, 1983) and Borrelia burgdorferi (Posey \& Gherardini, 2000), all living organisms have an absolute requirement for iron (Weinberg, 1978). The concentration of free iron in the human host is only $10^{-12} \mu \mathrm{M}$, however, resulting in conditions of iron starvation for invading microbes. Micro-organisms must therefore respond to iron limitation in the host environment for survival, either by secreting small, iron-chelating molecules (siderophores), or by robbing iron directly from host iron-binding proteins. The iron-withholding system of the human host is also an important environmental signal to which many bacteria respond by expressing a variety of virulence-associated genes (Litwin \& Calderwood, 1993).

Previous work in our laboratory applied inductively coupled argon plasma (ICAP) analysis (Coish \& Sinton, 1992) to reveal the iron content of human saliva. We defined salivary iron concentrations as ranging from $0 \cdot 1$ to $1.0 \mu \mathrm{M}$ (unpublished observations), and therefore included these concentrations in our in vitro studies. The growth of $S$. mutans was restricted in a medium containing $0.4 \mu \mathrm{M}$ iron, indicating that $S$. mutans is likely to experience iron starvation in the oral cavity, especially during non-mealtimes. The results of dialysis bag and chrome azural assays performed in our laboratory support a receptor-mediated mechanism for $S$. mutans iron uptake/transport (unpublished observations), which is consistent with previous reports in the literature indicating that $S$. mutans does not elaborate siderophores (Evans et al., 1986). Moreover, ferric chloride, ferric/ferrous citrate and transferrin all proved to be suitable iron sources for $S$. mutans growth in ironstarved cultures (data not shown). This is supported by reports that describe a membrane-associated flavin reductase in $S$. mutans that reduces ferric (III) iron into its more soluble ferrous (II) form prior to internalization (Evans et al., 1986). A transferrin receptor has not yet been identified in S. mutans, however, nor has one been described in other Gram-positive pathogens known to utilize transferrin as an iron source (Williams \& Griffiths, 1992).

The FimA lipoprotein is encoded by the last of three genes which comprise a tricistronic $\mathrm{ABC}$ transporter operon on the $S$. mutans chromosome (Kitten et al., 2000). The first ORF shares up to $62 \%$ amino acid identity with other streptococcal ATP-binding proteins, including ORF1 in S. gordonii (Kolenbrander et al., 1994) and PsaB in S. pneumoniae (Novak et al., 1998). The second shares up to $81 \%$ amino acid identity with other streptococcal hydrophobic transmembrane proteins within $\mathrm{ABC}$ transporter operons, including PsaA in S. gordonii (Kolenbrander et al., 1994) and FimB in $S$. parasanguis (Froeliger \& Fives-Taylor, 2000). The $S$. mutans fim $A$ gene product shares up to $76 \%$ amino acid identity with other streptococcal LraI proteins, including ScbA in S. cristae (Correia et al., 1996), Adc in $S$. pneumoniae (Dintilhac \& Claverys, 1997), ScaA in S. gordonii (Kolenbrander et al., 1994), and FimA in $S$. parasanguis (Fenno et al., 1995), all of which encode high-affinity metal ion transport proteins. That a fim $\mathrm{A}$ null mutation was not lethal in $S$. mutans indicates that other mechanisms for iron uptake/transport are functional in this oral pathogen. The presence of other iron transporters in S. mutans is also supported by the equivalent amounts of ${ }^{55} \mathrm{Fe}$ uptake we observed for the fim $A$ knockout mutant and its wild-type progenitor.

The results of Western and Northern blot analyses reveal an inverse relationship between $S$. mutans fimA expression and iron availability. This is consistent with a role for iron in the regulation of fim $A$ expression. In fact, located downstream of the $S$. mutans fim $A$ operon is a $654 \mathrm{bp} d t x R$-like gene $(d l g)$ which shares up to $54 \%$ similarity at the amino acid level with other irondependent repressor proteins including SirR in Staphylococcus epidermidis (Cockayne et al., 1998), TroR in Treponema pallidum (Hardham et al., 1997) and DtxR in Corynebacterium diphtheriae (Tao \& Murphy, 1994). Upstream of the $d l g$ start codon are putative ShineDalgarno, and -10 and -35 consensus sequences, indicating that $d l g$ expression may be driven by an independent promoter. Within the promoter region that precedes the $S$. mutans fimA operon is a $38 \mathrm{bp}$ inverted repeat (IR) sequence to which DtxR-like metalloregulatory proteins typically bind (Kitten et al., 2000). This suggests that expression of $d l g$ may also be controlled by the promoter that drives expression of the $\mathrm{ABC}$ transporter operon, resulting in transcriptional readthrough of fimA. Taken collectively, the structural organization of the $S$. mutans fimA locus is consistent with a role for the $d l g$ gene product in regulating ironresponsive fimA expression in $S$. mutans.

Gram-negative pathogens typically use Fur, a $17 \mathrm{kDa}$ cytosolic metalloregulatory protein that is also regulated by iron, to modulate the expression of genes important for virulence (Bullen et al., 1978; Finkelstein et al., 1983). Western blots performed in our laboratory revealed no evidence of a Fur-like homologue in $S$. mutans but confirmed the presence of a DtxR-like metalloregulator (data not shown). In Corynebacterium diphtheriae, DtxR utilizes iron to regulate virulence genes whose products are necessary for adherence and toxin production (Tao \& Murphy, 1994). MntR and IdeR are DtxR-like proteins in Bacillus subtilis (Que \& Helmann, 2000) and Mycobacterium tuberculosis (Pohl et al., 1999), respectively, which regulate manganese or iron uptake/transport functions. In the present study, we propose a model for Dlg metalloregulation in $S$. mutans that may involve the formation of $\mathrm{Dlg}-\mathrm{Fe}^{2+}$ complexes. Specifically, we propose that when iron is plentiful, Dlg- $\mathrm{Fe}^{2+}$ complexes form and associate with the IR sequence upstream of the $S$. mutans fimA operon, thereby decreasing iron uptake by down-regulating 


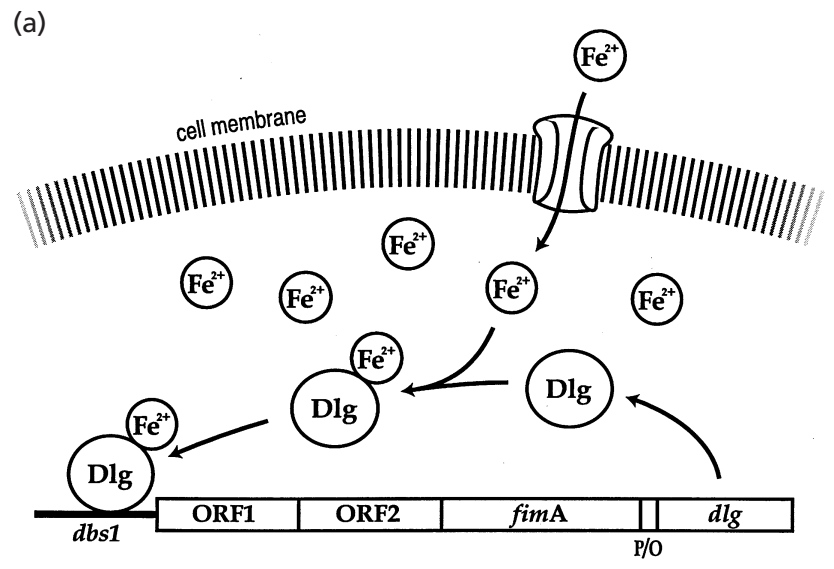

(b)

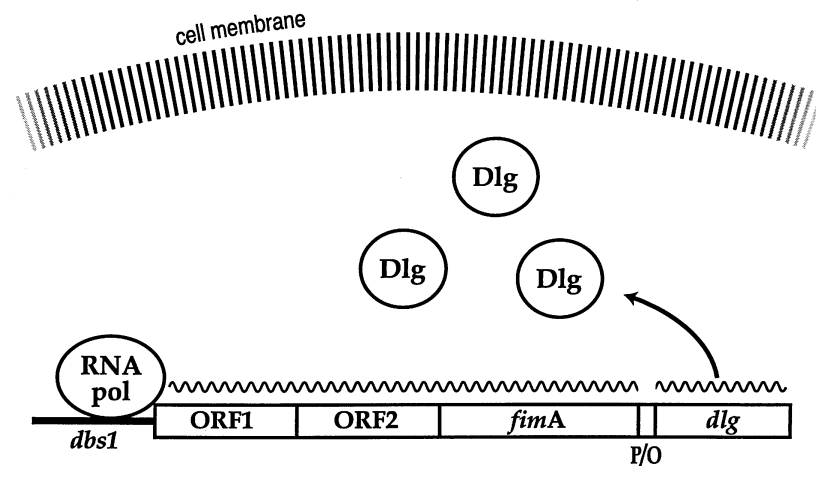

Fig. 7. Proposed metalloregulation of the $S$. mutans fimA operon by Dlg. (a) In the presence of $\mathrm{Fe}^{2+}$, we propose that $\mathrm{Dlg} \mathrm{Fe}^{2+}$ complexes form and bind to an inverted repeat sequence ( $d b s 1)$ located upstream of the $S$. mutans fimA operon. This would prevent transcription of the operon by RNA polymerase, and so inhibit expression of fimA and possibly other virulence genes within this putative regulon. (b) In the absence of $\mathrm{Fe}^{2+}, \mathrm{Dlg}-\mathrm{Fe}^{2+}$ complexes are not likely to form. As a result, the $S$. mutans fimA operon would become derepressed so that fimA may be actively transcribed.

expression of the fimA iron transporter (Fig. 7a). In contrast, when iron is limiting, as it is in the human host, we propose that $\mathrm{Fe}^{2+}$ is not available as a co-repressor to complex with Dlg. Thus, Dlg cannot bind at the IR sequence and fimA expression is likely to become derepressed, thereby promoting iron scavenging (Fig. $7 \mathrm{~b})$. Evidence supporting this model includes the increase in fimA expression noted for the GMS800 $d l g$ knockout mutant on Western and Northern blots, and the increase in ${ }^{55} \mathrm{Fe}$ uptake by GMS800 which is compromised in the $f \mathrm{~mA} / \mathrm{dlg}$ double knockout mutant, GMS850. Taken collectively, these findings indicate that Dlg is a repressor of $S$. mutans fim $A$ expression, and that the fim $A$ gene product is involved in iron transport in this oral pathogen. Gel mobility shift assays are currently under way in our laboratory to confirm the $S$. mutans IR sequences as putative Dlg-binding sites.

$\mathrm{ABC}$ transporter systems with a requirement for manga- nese have been described in S. gordonii (Kolenbrander et al., 1998), S. parasanguis (Fenno et al., 1995) and S. pneumoniae (Dintilhac et al., 1997), and conserved nucleotides within the $S$. mutans $d l g$ sequence support a putative interaction between Dlg and $\mathrm{Mn}^{2+}$. In addition, a manganese requirement for $S$. mutans is supported by the $\mathrm{Mn}^{2+}$ specificity of its superoxide dismutase (Nakayama, 1992). However, while growth-curve experiments in our laboratory support manganese as an essential micronutrient for $S$. mutans growth (unpublished observations), the results of metal ion uptake assays do not implicate the $S$. mutans fimA ABC transporter or Dlg in manganese uptake.

Finally, the disruption of $d l g$ did not affect $S$. mutansinduced cariogenesis in germ-free rats. This is not surprising since the expression of virulence factors is paramount for bacterial survival in the host environment. Indeed, the expression of genes whose products promote $S$. mutans caries development is likely to be subject to multiple mechanisms of control, not all of which belong to the proposed Dlg regulon. We also noted that the cariogenic potential of $S$. mutans was not significantly affected by a fim $A$ knockout mutation in a rat caries model. This is consistent with a recent report by Froeliger \& Fives-Taylor (2000) suggesting that FimA is not significantly involved in $S$. parasanguis adhesion to saliva-coated hydroxyapatite. However, recent in vivo studies support a role for $S$. mutans FimA in an endocarditis model (Burnette-Curley et al., 1995; Kitten et al., 2000). We propose that fimbrial adhesins, rather than the glucan products of sucrose-dependent glucosyltransferases, mediate adherence when S. mutans translocates into the bloodstream. This is supported by previous work in our laboratory which revealed induction of fimA expression upon exposure of $S$. parasanguis cultures to horse or bovine serum (unpublished observations). How iron might be involved in mediating the expression of fim $A$ under these host conditions has not yet been determined.

\section{ACKNOWLEDGEMENTS}

We thank Dr Paula Fives-Taylor for providing the anti-FimA polyclonal antiserum and for helpful discussions and review of the manuscript. We also thank Dr Eunice Froeliger for her assistance with metal ion uptake assays, Dr Vicki Backus for her help with statistical analyses, and Katherine Wagner for her technical expertise. This work was supported by the National Institute of Dental and Craniofacial Research Small Grant Program \#DE12270 to G. Spatafora, by the American Society for Microbiology in an Undergraduate Research Fellowship to M. Moore, and by the Middlebury College Department of Biology.

\section{REFERENCES}

Adkins, B. L. \& Losee, F. L. (1970). A study of covariation of dental caries prevalence and multiple trace element content of water supplies. N Y State Dent J 36, 618-622.

Aranha, H., Strachan, R. C., Arceneaux, J. \& Byers, B. (1982). Effect of trace metals on growth of Streptococcus mutans in a teflon chemostat. Infect Immun 35, 456-460. 
Archibald, F. (1983). Lactobacillus plantarum, an organism not requiring iron. FEMS Microbiol Lett 19, 29-32.

Boyd, J., Oza, M. N. \& Murphy, J. (1990). Molecular cloning and DNA sequence analysis of a diphtheria tox iron-dependent element $(d t x R)$ from Corynebacterium diphtheriae. Proc Natl Acad Sci U S A 87, 5968-5972.

Bullen, J. J., Rogers, H. J. \& Griffiths, E. (1978). Role of iron in bacterial infections. Curr Top Microbiol Immunol 80, 1-35.

Burnette-Curley, D., Wells, V., Viscount, H., Munro, C. L., Fenno, J. C., Fives-Taylor, P. \& Macrina, F. L. (1995). FimA, a major virulence factor associated with Streptococcus parasanguis endocarditis. Infect Immun 63, 4669-4674.

Butteron, J., Stoebner, J., Payne, S. \& Calderwood, S. (1992). Cloning, sequencing, and transcriptional regulation of viuA, the gene encoding the ferric vibriobactin receptor in Vibrio cholerae. J Bacteriol 174, 3729-3738.

Cockayne, A., Hill, P. J., Powell, N. B., Bishop, K., Sims, C. \& Williams, P. (1998). Molecular cloning of a 32 kilodalton lipoprotein component of a novel iron-regulated Staphylococcus epidermidis ABC tansporter. Infect Immun 66, 3767-3774.

Coish, R. A. \& Sinton, C. W. (1992). Geochemistry of mafic dikes in the Adirondack mountains: implications for late Proterozoic continental rifting. Contrib Mineral Petrol 110, 500-514.

Correia, F. F., DiRienzo, J. M., McKay, T. L. \& Rosan, B. (1996). scbA from Streptococcus crista CC5A: an atypical member of the IraI gene family. Infect Immun 64, 2114-2121.

Dintilhac, A. \& Claverys, J. P. (1997). The adc locus, which affects competence for genetic transformation in Streptococcus pneumoniae, encodes an ABC transporter with a putative lipoprotein homologous to a family of streptococcal adhesins. Res Microbiol 148, 119-131.

Dintilhac, A., Alloing, G., Granadel, C. \& Claverys, J. P. (1997). Competence and virulence of Streptococcus pneumoniae: AdcA and PsaA mutants exhibit a requirement for $\mathrm{Zn}$ and $\mathrm{Mn}$ resulting from inactivation of putative $\mathrm{ABC}$ metal permeases. Mol Microbiol 25, 727-739.

Evans, S., Arceneaux, J., Byers, B., Martin, M. \& Aranha, H. (1986). Ferrous iron transport in Streptococcus mutans. J Bacteriol 168, 1096-1099.

Federle, M. J., Mclver, K. S. \& Scott, J. R. (1999). A response regulator that represses transcription of several virulence operons in the group A streptococcus. J Bacteriol 181, 3649-3657.

Fenno, J. C., Shaikh, A., Spatafora, G. \& Fives-Taylor, P. (1995). The fimA locus of Streptococcus parasanguis encodes an ATPbinding membrane transport system. Mol Microbiol 15, 849-863.

Finkelstein, R., Sciortino, C. \& Mclntosh, M. (1983). Role of iron in microbe-host interactions. Rev Infect Dis 5, S759-S777.

Fleming, T., Nahlika, M. \& Mclntosh, M. (1983). Regulation of enterobacteria iron transport in Escherichia coli: characterization of ent: : $\operatorname{Mud}\left(\mathrm{Ap}^{\mathrm{r}} \mathrm{lac}\right)$ operon fusions. J Bacteriol 156, 1171-1177.

Froeliger, E. H. \& Fives-Taylor, P. (2000). Streptococcus parasanguis FimA does not contribute to adherence to SHA (abstract). J Dent Res 79, 337.

Ganeshkumar, N., Hannam, P. M., Kolenbrander, P. E. \& McBride, B. C. (1991). Nucleotide sequence of a gene coding for a salivabinding protein $(\mathrm{SsaB})$ from Streptococcus sanguis 12 and possible role of the protein in coaggregation with Actinomyces. Infect Immun 59, 1093-1099.

Goodman, S. D. \& Gao, Q. (2000). Characterization of the gtfB and gtfC promoters from Streptococcus mutans GS-5. Plasmid 4, $85-98$.
Genco, C. \& Desai, P. (1996). Iron acquisition in the pathogenic Neisseria. Trends Microbiol 4, 185-191.

Hardham, J. M., Stamm, L. V., Porcella, S. F. \& 7 other authors (1997). Identification and transcriptional analysis of a Treponema pallidum operon encoding a putative $\mathrm{ABC}$ transport system, an iron-activated repressor protein homolog, and a glycolytic pathway enzyme homolog. Gene 197, 47-64.

Hennecke, H. (1990). Regulation of bacterial gene expression by metal-protein complexes. Mol Microbiol 4, 1621-1628.

Husson, M., Legrand, D., Spik, G. \& Leclerc, H. (1993). Iron acquisition by Helicobacter pylori: importance of human lactoferrin. Infect Immun 61, 2694-2697.

Janulcyk, R., Pallon, J. \& Björck, L. (1999). Identification and characterization of a Streptococcus pyogenes ABC transporter with multiple specificity for metal cations. Mol Microbiol 344, 596-606.

Keyes, P. (1958). Dental caries in the molar teeth of rats. II. A method for diagnosing and scoring several types of lesions simultaneously. J Dent Res 37, 1088-1099.

Kitten, T., Munro, C. L., Michalek, S. M. \& Macrina, F. L. (2000). Genetic characterization of a Streptococcus mutans LraI family operon and role in virulence. Infect Immun 68, 4441-4451.

Kolenbrander, P. E., Andersen, R. N. \& Ganeshkumar, N. (1994). Nucleotide sequence of the Streptococcus gordonii PK488 coaggregation adhesin gene, scaA, and ATP-binding cassette. Infect Immun 62, 4469-4480.

Kolenbrander, P. E., Andersen, R. N., Baker, R. A. \& Jenkinson, H. F. (1998). The adhesion-associated sca operon in Streptococcus gordonii encodes an inducible high-affinity $\mathrm{ABC}$ transporter for $\mathrm{Mn}^{2+}$ uptake. J Bacteriol 180, 290-295.

Laemmli, U. K. (1970). Cleavage of structural proteins during the assembly of the head of bacteriophage T4. Nature 227, 680-685. Litwin, C. M. \& Calderwood, S. B. (1993). Role of iron in regulation of virulence genes. Clin Microbiol Rev 6, 137-149.

Marmur, J. (1961). A procedure for the isolation of deoxyribonucleic acid from microorganisms. J Mol Biol 3, 208-218.

Michalek, S., McGhee, J. \& Navia, J. (1975). Virulence of Streptococcus mutans: a sensitive method for evaluating cariogenicity in young gnotobiotic rats. Infect Immun 12, 69-75.

Nakayama, K. (1992). Nucleotide sequence of Streptococcus mutans superoxide dismutase gene and isolation of insertion mutants. J Bacteriol 174, 4928-4934.

Novak, R., Braun, J. S., Charpentier, E. \& Tuomanen, E. (1998). Penicillin tolerance genes of Streptococcus pneuomoniae: the ABC-type manganese permease complex, Psa. Mol Microbiol 29, 1285-1296.

Pohl, E., Holmes, R. K. \& Hol, W. G. J. (1999). Crystal structure of the iron-dependent regulator (IdeR) from Mycobacterium tuberculosis shows both metal binding sites fully occupied. $J$ Mol Biol 285, 1145-1156.

Posey, J. E. \& Gherardini, F. C. (2000). Lack of a role for iron in the Lyme disease pathogen. Science 288, 1651-1653.

Que, Q. \& Helmann, J. D. (2000). Manganese homeostasis in Bacillus subtilis is regulated by $\mathrm{MntR}$, a bifunctional regulator related to the diphtheriae toxin repressor family of proteins. Mol Microbiol 35, 1454-1468.

Rigby, P. W. J., Dieckman, M., Phodes, C. \& Berg, P. (1977). Labeling deoxyribonucleic acid to high specific activity in vitro by nick translation with DNA polymerase. I. J Mol Biol 113, 237-251.

Sambrook, J., Fritsch, E. F. \& Maniatis, T. (1989). Molecular 
Cloning: a Laboratory Manual, 2nd edn. Cold Spring Harbor, NY : Cold Spring Harbor Laboratory.

Schiering, N., Tao, X., Zeng, H., Murphy, J., Petsko, G. \& Ringe, D. (1995). Structures of the apo- and the metal ion-activated forms of the diphtheria tox repressor from Corynebacterium diphtheriae. Proc Natl Acad Sci US A 92, 9843-9850.

Schmidt, M. (1997). Transcription of the Corynebacterium diphtheriae $h m u \mathrm{O}$ gene is regulated by iron and heme. Infect Immun 65, 4634-4641.

Schwyn, B. \& Neilands, J. B. (1987). Universal chemical assay for the detection and determination of siderophores. Anal Biochem 160, 47-56.

Southern, E. M. (1975). Detection of specific sequences among DNA fragments separated by gel electrophoresis. J Mol Biol 98, 503-517.

Spatafora, G. \& Moore, M. (1998). Growth of Streptococcus mutans in an iron-limiting medium. Methods Cell Sci 20, 217-221.

Spatafora, G., Rohrer, K., Barnard, D. \& Michalek, S. (1995). A Streptococcus mutans mutant that synthesizes elevated levels of intracellular polysaccharide is hypercariogenic in vivo. Infect Immun 63, 2556-2563.

Spellerberg, B., Rozdzinski, E., Martin, S., Weber-Heynemann, J., Schnitzler, N., Lütticken, R. \& Podbielski, A. (1998). Lmb, a protein with similarities to the LraI adhesin family, mediates attachment of Streptococcus agalactiae to human laminin. Infect Immun 67, 871-878.

Tao, X. \& Murphy, J. R. (1994). Iron, DtxR, and the regulation of diphtheria toxin expression. Mol Microbiol 14, 191-197.

Terleckyj, B., Willett, N. P. \& Shockman, G. D. (1975). Growth of several cariogenic strains of oral streptococci in a chemically defined medium. Infect Immun 11, 649-655.

Viscount, H. B., Munro, C. L., Burnette-Curley, D., Peterson, D. L. \& Macrina, F. L. (1997). Immunization with FimA protects against Streptococcus parasanguis endocarditis in rats. Infect Immun 65, 994-1002.

Weinberg, E. D. (1978). Iron and infection. Microbiol Rev 42, 45-66.

Williams, P. \& Griffiths, E. (1992). Bacterial transferrin receptors structure, function, and contribution to virulence. Med Microbiol Immunol 181, 301-322.

Wooldridge, K. G. \& Williams, P. H. (1993). Iron uptake mechanisms of pathogenic bacteria. FEMS Microbiol Rev 12, 325-348.

Zimmerman, L., Hantke, K. \& Braun, V. (1984). Exogenous induction of the iron dicitrate transport system of Escherichia coli K-12. J Bacteriol 159, 271-277.

Received 23 January 2001; accepted 2 March 2001. 